\title{
THE TESTING OF MONEY NEUTRALITY IN ECONOMIC GROWTH OF INDONESIA
}

Muammil Sun'an

Faculty of Economics, University of Khairun,

Ternate, Indonesia

E-mail: amilabdulrahman77@gmail.com

Amran Husen

Faculty of Economics,

University of Khairun,

Ternate, Indonesia

\begin{abstract}
This study aim is to test the money neutrality in a narrow sense (M1) and a broad sense (M2) to the growth of output (GDP) in Indonesia, both in short term and long term. This research uses quarterly time series data at 2010 - 2016 periods. The analysis tool used is Error Correction Model (ECM). The results show that shortterm money supply ( $\mathrm{M}_{1}$ and $\mathrm{M}_{2}$ ) affect on output growth. However, in the long term, only money circulation in a broad sense (M2) affects on output growth, which also means that money is not neutral because it affects the real sector (GDP).
\end{abstract}

Keywords: M1, M2, Population, Capital, and Economic Growth.

| Received November 2017 | Accepted December 2017 | Available online December 2017 |

| DOI: http://dx.doi.org/10.18860/mec-j.v1i1.4575

\section{INTRODUCTION}

One important indicator to analyze the economic development in a country is economic growth. It is measured by difference in gross domestic product (GDP) of a certain year and the previous year (Setiawan and Handoko, 2005). The money supply is the main instrument of Bank Indonesia to achieve economic objectives such as price stability and output growth. However, according to the classical economist, money is neutral because the changes in money supply will only affect on nominal variables such as price levels and do not affect real variables such as output levels. According to Lucas (1995), the money neutrality is described as a situation where changes in money supply will only changes the nominal variables, such as price, nominal exchange rate and nominal wages, without causing changes in real variables such as output, consumption, investment and employment. This idea was conveyed by classical economist (Hume, 1752) that the increase in money supply had no effect on employment or investment and level or growth of output.

Some economists argue that because money has an important role as atool of transactions in all economic life, then money also has an important role in process of community production. Therefore, these economists argue that money is productive, in sense that money has a role in production process, unlike other physical inputs (such as capital and labor). The entry of money into the production function, the "money" will affect the long-term equilibrium position of economy. In the literature, question of whether or not "money" affects the "real" aspect of economy (in this case, output growth) are often referred to as a matter of money neutrality. Money is "neutral" if it does not affect the "real" sector, and not neutral if it is influential. This all ultimately depends on proposed model. However, many economists now argue that money is not neutral (Boediono, 1981).

Money neutrality study was first examined by King and Watson $(1992,1997)$ in United States who found that money did not affect real output in long run. Sulku (2011) also 
examines the money neutrality in Turkey to finds that money is neutral to real output. Both of these studies support the long-term money neutrality in economy but there have been studies to found that money neutrality does not occur in economies. Puah et al (2006) found that there was no long-term money neutrality for Malaysian state. A study by Ekomie (2013) also found that long-term money neutrality did not apply to all EMCCA countries, and then the research of Arintoko (2011) found that long-term money neutrality also does not occur in Indonesia.

Based on above explanation, it can be concluded that achievement or economic growth targets is not only affect the real variables, but also the impact of monetary variables. One of them is the role of money to influence the economy of a country. This means that money can also affect the economy balance in long term.

More specifically, this study attempts to: (1) analyze the effect of capital growth, population growth, and money in narrow sense (M1) and money in broad sense $\left(M_{2}\right)$ to the level of economic output in Indonesia; and (2) to analyze the influence of money on output growth in Indonesia.

\section{LITERATURE REVIEW}

\section{The role of money in growth}

The growth models we discussed up to this point do not give a clear role to "money" in growth process. All see the process of economic growth as a "real" process, meaning it does not concern the existence or role of money in economic life. The growth process is seen as a process involving an increase in output, to be determined by "rill" factors as well, for example, by rate of capital accumulation ("capital" in real sense, in form of machines and auxiliaries in production process), rate of population growth, rate of technological advancement and innovation, amount of available natural resources, etc. One exception may be said of Schumpeter's theory, which emphasizes the role of credit systems in innovation process, but this theory does not provide a clear role to "money" in economic life and growth process.

The question of whether "money" affects or does not affect the "real" aspect of economy (in this case, output growth) is often referred to as the issue of net worth of money. Money is "neutral" if it does not affect the "real" sector and neutral if it is influential. This all ultimately depends on proposed model. However, many economists now think that money is not neutral.

The answer to this question is crucial, because if the money can indeed change the characteristics of equilibrium path, then this means that monetary policy (which is nothing but the policy of managing money in economy) can be used to influence the rate the growth of economy balance. Furthermore, it can also be asked about what "optimal" monetary policy for economic growth (Boediono, 1981).

\section{Money and Growth Parameters}

Answering whether the inclusion of money into the growth model becomes the hallmark of growth path of equilibrium change. We need to remember what determining factors of equilibrium growth path in growth model without money. We can ask whether the any factors are affected by inclusion of money into the model. If there is, this means that path of equilibrium growth itself is also affected by existence of money in economy. Therefore, the money is "not neutral". However, if these factors are not affected by money, then money is "neutral". Neo-Classical model has four main parameters to determine the position, shape and characteristics of growth path of equilibrium. These four parameters are population growth rate $(n)$, technological progress rate $(t)$, production function $(f(k))$, 
and propensity to save (s). The first two parameters, $\mathrm{n}$ and $\mathrm{t}$, can be considered as unaffected by money. That is, in Neo-Classical growth theory that has been developed, these two parameters have always been considered to be given value (i.e., considered "exogenous"). However, the other two parameters, $f(k)$ and $s$, are thought to be affected by money. Through these two parameters, the "money" can have an effect on of balance growth influenced. Let us see how this happens.

The production function $q=f(k)$ comes from original production function

$$
\mathrm{Q}=\mathrm{F}(\mathrm{K}, \mathrm{L})
$$

Some economists argue that because money has an important role as a tool of transactions in all economic life, then money has an important role in process of community production. Money makes transactions become smoother and cheaper, resulting in less human labor (L) in transaction settlement, and less capital (K) for the transaction settlement. Another example is that with money, producer can reduce the inventory of capital goods and materials he must store, as inventories; it is enough to keep the minimum amount and rest can be stored in form of money. In terms of society, more stock of capital can be "liberated" as stock and used in real production process (K). Therefore, these economists argue that money is productive, in sense that it has a role in production process, not unlike the physical inputs $(\mathrm{K}, \mathrm{L})$. If this is the case, the production function of society must include money as one input,

$$
\mathrm{Q}=\mathrm{F}(\mathrm{K}, \mathrm{L}, \mathrm{M} / \mathrm{P})
$$

Where $M$ is the nominal amount of money supply circulating in society and $P$ is the general price level. M / P is the money stock measured in according to purchasing power, and in economic theory is called the real cash balance or real cash balance. The productive is not the nominal value of money stock, but the money stock as a means of transaction (should measured basis on purchasing power). For example, if $M$ goes up by $10 \%$ and $P$ rises by $10 \%$, then the nominal amount of money stock goes up by $10 \%$, but its purchasing power (or the ability to buffer transactions) is fix, as prices go up by $10 \%$ too. This means that "productivity" of money in circulation is not increased. "Productivity" will increase if $M$ goes up more than $\mathrm{P}$, or if real cash balance $(\mathrm{M} / \mathrm{P})$ rises.

The entrance of $M / P$ into the production function makes the "money" will affect the long-term equilibrium position of economy. Later we will discuss further the consequences of this presumption for position of balance.

\section{METHODS}

\section{Data and Resources}

This research measure the relationship among the macroeconomic variables based on an economic theory and then elaborated into econometric model. It is support by data and processed by statistical methods to obtain value of economic relationship parameters of economic variables.

This research uses secondary data of time series. Data were taken from related institutions with research problems, such as Central Bureau of Statistics (BPS), Bank Indonesia Report (SEKI) and other sources.

\section{Data analysis method}

One of most common dynamic models applied to non-stationary data is the Error Correction Model (ECM) by Domowitz-Elbadawi. ECM can describe the long-term relationships between variables and balancing them in short term. Widarjono (2016) explained that the ECM Domowitz-Elbadawi model is valid if the ECM coefficient is positive and statistically significant, or $0<E C T<$ one. 
The simple terms of general model in this study is $Q=f(K, L, M / P)$. The error correction model used in this study is follows:

$$
\operatorname{Ln}(P E)=\beta 0+\beta 1 \operatorname{Ln}(K)+\beta_{2} \operatorname{Ln}(L)+\beta_{3} \operatorname{Ln}(M 1)+\beta 4 \operatorname{Ln}(M 1)+\beta_{5} E C T t-1+\varepsilon t
$$

$E C T t-1$ is a cointegration error lag 1 , or mathematically can be written as follows:

$\mathrm{ECTt}-1=$ PEt-1 - $3 \mathrm{O}-\mathrm{Kt}-1-\mathrm{Lt}-1-\mathrm{M} 1 \mathrm{t}-1-\mathrm{M} 1 \mathrm{t}-1$

Note:

PE: Economic Output

K: Capital / Investment

L: Labor

M1: Money circulation in a narrow sense

M2: Money circulation in a broad sense

$\beta_{0}$ : Constantine / Intercept

$\beta_{1}, \ldots \beta_{4}$ : Regression coefficients of independent variables

ECT: Error Correction Term

$\varepsilon_{\mathrm{t}}$ : Variable error error

\section{RESULTS}

\section{Data Stationary Testing (Unit root test)}

Regression without stationary time series can create spurious regression. Regression occurs when the coefficient of determination is quite high but the relationship between the independent variable and dependent variable has no meaning. This happens because the relationship between the two is time series, the data only shows the trend. The high coefficient of determination is happened because the trend is not because of relationship between the two (Widarjono, 2005).

Comparing the ADF statistical value and its critical value procedure is used to determine whether the data is stationary or not. If the absolute value of ADF statistic is greater than the critical value, then the observed data indicates stationary and if otherwise the data is not stationary. If in root test the unit yields the conclusion that data is not stationary, then the next step is the degree of integration test (Gujarati, 1995; Insukindro, 1993).

Table 1. Results of Data Station Stability Testing

\begin{tabular}{lcccc}
\hline \multicolumn{1}{c}{ Variables } & \multicolumn{4}{c}{ Unit Square Test } \\
\hline \hline & ADF & Prob & ADF & Level \\
\hline \hline PDB & $2.3055^{*}$ & 0.9926 & $-4.7656^{*}$ & 0.0001 \\
\hline \hline K & $2.1341^{*}$ & 0.9893 & $-4.8790^{*}$ & 0.0000 \\
\hline \hline Pop & $3.2300^{*}$ & 0.1033 & $-5.2838^{*}$ & 0.0000 \\
\hline \hline M1 & $2.0171^{*}$ & 0.9863 & $-4.6287^{*}$ & 0.0001 \\
\hline \hline Description : * significant 1\%, 5\%, dan 10\%. & 0.9927 & $-4.7265^{*}$ & 0.0001 \\
\hline
\end{tabular}

Table 1 shows that all variables are turn out stationary at level or on original data, I (0). Therefore, it can be done next step testing. All time series data in this study (PE, K, L, and $M / P$ ) have the same mean, variance and covariance values on each lag and remain same at all times. In other words, it has been constant and unchanged in all the time (Widarjono, 2016). The next important implication is the results of this research analysis will avoid the possibility of spurious regression.

\section{Cointegration Testing}


Principally the cointegration approach is used to test the long-term equilibrium relationship between economic variables as desired by economic theory. This approach may also be viewed as a test of theory and an important part of formulation and estimation of empirical models, especially the dynamic model (Sriyana, 2003).

If residual et does not contain unit roots or stationary data at level I (0) then the relationship between research variables is cointegrated. It means has long term relationship. Generally it can be said that if time series data $Y$ and $X$ are not stationary at level but become stationary on same difference $(Y)$ is I (d) and $X$ is I (d) where $d$ is the has same level of difference then both data is cointegrated. In other word, the cointegration test can only be done when the data used in research is integrated on same degree, as shown in table 2.

Table 2. Root Test Unit of residual variables

\begin{tabular}{ccc}
\hline Variables & ADF, I(0) & Test critical values \\
\hline ECT & -4.578226 & -4.571559 \\
& & -3.690814 \\
& & -3.286909 \\
\hline
\end{tabular}

Description: ${ }^{*}$ ) Significant at a $1 \%, 5 \%$, and $10 \%$.

Table 2 shows that data of all variables including residual values are integrated at same level, I (0). These means that all observed variables have been cointegrated to the original data. Therefore, it can be said that there is a long-term equilibrium relationship between research variables ( $P E, K, L, M 1$, and $M 2$ ).

\section{Estimation of Linear Regression Model}

Based on problems and research hypotheses, the influence of money circulation in society ( $\mathrm{M}_{1}$ and $\left.\mathrm{M}_{2}\right)$ on economic growth of Indonesia are proved empirically. This means that this research can be accepted as a scientific knowledge, which has authenticated an empirical theory.

\section{Partial Regression Coefficient Test ( $t$ test)}

Testing the partial regression coefficient is a test of relationship between research variables separately. The influence of independent variables is partially represented by magnitude of each $t$ statistic value, as shown in table 2.

Table 3. Linear Regression Testing

\begin{tabular}{|c|c|c|c|c|}
\hline \multicolumn{5}{|c|}{ Dependent Variable: PDB } \\
\hline \multicolumn{5}{|l|}{ Method: Least Squares } \\
\hline \multicolumn{5}{|c|}{ Date: $12 / 03 / 17$ Time: $17: 59$} \\
\hline \multicolumn{5}{|l|}{ Sample: 2011Q1 2016Q4 } \\
\hline \multicolumn{5}{|c|}{ Included observations: 24} \\
\hline Variable & Coefficient & Std. Error & t-Statistic & Prob. \\
\hline M1 & -0.019187 & 0.003306 & -5.803409 & 0.0000 \\
\hline $\mathrm{M} 2$ & 0.376627 & 0.009435 & 39.91736 & 0.0000 \\
\hline L & 0.277675 & 0.009807 & 28.31293 & 0.0000 \\
\hline K & 0.072114 & 0.028160 & 2.560892 & 0.0191 \\
\hline $\mathrm{C}$ & 2.564866 & 0.093717 & 27.36824 & 0.0000 \\
\hline R-squared & 0.999920 & Mean depende & & 6.318374 \\
\hline Adjusted R-squared & 0.999903 & S.D. dependen & & 0.039331 \\
\hline S.E. of regression & 0.000387 & Akaike info crit & & -12.69275 \\
\hline Sum squared residue & $2.85 \mathrm{E}-06$ & Schwarz criteri & & -12.44732 \\
\hline Log likelihood & 157.3130 & Hannan-Quinn & & -12.62764 \\
\hline F-statistic & 59356.86 & Durbin-Watson & & 1.068785 \\
\hline Prob(F-statistic) & 0.000000 & & & \\
\hline
\end{tabular}


Table 3 shows that partially independent variables ( $M 1, M 2, K$, and $L)$ has significant influence on the economic growth of Indonesia. This is indicated by a t-statistic value greater than the t-table value at $a 5 \%$ or a probability values are below 0.05 . The Classical view suggests that changes in money supply will only affect the rate of inflation, not economic growth. This means that if money does not affect the "real" aspect of economy then the money is said to be "neutral". The test results show that change in money supply (M1 and $M_{2}$ ) also affects on output growth, it can be said that money is not neutral.

\section{Simultaneous Regression Coefficient Test (F Test)}

Testing the regression coefficient simultaneously is is used to test the influence of independent variables simultaneously to the dependent variable. The result is indicated by magnitude of $\mathrm{F}$ statistic.

Table 3 shows that simultaneously the independent variables (capital growth, population growth, and money supply in community) have a positive effect on dependent variable (economic growth of Indonesia). The effect of variables is significant at a $1 \%$, which shows the amount of F-statistic greater than the F-table value.

Similarly, magnitude of proportion or variation of changes in economic growth is determined by each independent variables at Adjusted R-squared value of 0.9999 or $99.99 \%$ economic growth determined by amount of capital growth, population growth and money supply ( $\mathrm{M}_{1}$ and $\mathrm{M}_{2}$ ). While the remaining $0.1 \%$ of economic growth is determined by other variables outside the research model.

\section{Estimation of Error Correction Model}

Error Correction Model (ECM) has been widely applied in econometric analysis for time series data, supported by ECM capability to cover more variables to analyze short term and long term economic phenomena. ECM model has advantages especially in effort to find solutions to the problem non stationarity of time series variables, spurious regression and false correlation in econometric analysis (Insukindro, 1999).

Table 4. Estimation of Error Correction Model

\begin{tabular}{|c|c|c|c|c|}
\hline \multicolumn{5}{|c|}{ Dependent Variable: PDB } \\
\hline \multicolumn{5}{|c|}{ Method: Least Squares } \\
\hline \multicolumn{5}{|c|}{ Date: 12/03/17 Time: $21: 36$} \\
\hline \multicolumn{5}{|c|}{ Sample (adjusted): 2011Q2 2016Q4 } \\
\hline \multicolumn{5}{|c|}{ Included observations: 23 after adjustments } \\
\hline Variable & Coefficient & Std. Error & t-Statistic & Prob. \\
\hline $\mathrm{C}$ & 2.543080 & 0.052753 & 48.20734 & 0.0000 \\
\hline $\mathrm{K}$ & 0.060524 & 0.014991 & 4.037359 & 0.0014 \\
\hline POP & 0.270572 & 0.006054 & 44.69166 & 0.0000 \\
\hline M1 & -0.016630 & 0.001959 & -8.490346 & 0.0000 \\
\hline $\mathrm{M} 2$ & 0.383686 & 0.005381 & 71.30902 & 0.0000 \\
\hline M1(-1) & -0.001854 & 0.001961 & -0.945349 & 0.3617 \\
\hline $\mathrm{M} 2(-1)$ & -0.010326 & 0.005339 & -1.934009 & 0.0752 \\
\hline $\mathrm{K}(-1)$ & 0.018509 & 0.014929 & 1.239761 & 0.2370 \\
\hline $\mathrm{POP}(-1)$ & 0.005465 & 0.005992 & 0.912026 & 0.3784 \\
\hline $\mathrm{ECT}(-1)$ & 0.650415 & 0.126134 & 5.156529 & 0.0002 \\
\hline R-squared & 0.999987 & \multicolumn{2}{|c|}{ Mean dependent var } & 6.320482 \\
\hline Adjusted R-squared & 0.999979 & \multicolumn{2}{|c|}{ S.D. dependent var } & 0.038804 \\
\hline S.E. of regression & 0.000180 & \multicolumn{2}{|c|}{ Akaike info criterion } & -14.11041 \\
\hline Sum squared resid & $4.20 \mathrm{E}-07$ & \multicolumn{2}{|c|}{ Schwarz criterion } & -13.61671 \\
\hline Log likelihood & 172.2697 & \multicolumn{2}{|c|}{ Hannan-Quinn criter. } & -13.98624 \\
\hline F-statistic & 113851.3 & \multicolumn{2}{|c|}{ D Durbin-Watson stat } & 1.636310 \\
\hline Prob(F-statistic) & 0.000000 & & & \\
\hline
\end{tabular}


Table 4 shows the ECM Domowitz-Elbadawi estimation for price level equation has positive (0.6504) error correction variable coefficient and lies between 0 and 1 ( $0<0.6504$ $<1)$, and statistically significant ( $p$-value $0.0002<0.05$ ). It means the model specification ECM Domowitz-Elbadawi used in this study is valid (Widarjono, 2013).

The Error Correction (EC) value of 0.6504 reflects the level of balance, or speed of adjustment to return to the balance level. The difference between the values of dependent variable (output growth) with equilibrium value of 0.6504 will be adjusted within 4 months.

The coefficient ECT (-1) variable is significant at a $5 \%$. It means the errors of balance affect on economy output. It can be interpreted that output growth (GDP) adjusts the change of independent variables (K, L, M1, and $\left.\mathrm{M}_{2}\right)$ in same period. In other words, it one next period adjustment to follow long-term period is not so meaningful, because the coefficient value is only $65 \%$.

\section{DISCUSSION}

\section{The effect of capital on economic growth}

The growth process is seen as a process involving an increase in output that determined by "rill" factors, for example by rate of capital accumulation ("capital" in real sense, in form of machines and auxiliaries in production process), population growth rate, technological progress and innovation, amount of available natural resources and others.

Hypothesis testing shows that capital growth has a positive effect on economic growth of Indonesia. This means that there is a direct relationship between capital growth and economic growth. Therefore, it can be said that the increase in capital will raise the goods and services produced in economy, which ultimately increase economic growth. Therefore, Solow growth model is very appropriate in explaining the condition of Indonesian economy, which states that accumulation of capital through investment is one of requirements to achieve certain economic growth targets. Capital accumulation is a necessary condition to accelerate the level of economic development. This is consistent with King and Levine (1994) which states that capital accumulation is not a "source of trigger" of economic growth, but capital accumulation is only "part of process" of economic growth.

\section{The effect of population on economic growth}

Population growth improves the Solow model in three ways. First, Solow model can explain sustainable economic growth. In steady state the capital per labor and output per labor is unchanged. Since the growth of labor is $\mathrm{N}$, total capital and output also grow at $\mathrm{N}$ level. Therefore, population growth cannot account for continued growth in standard of living because the output per worker remains at steady state. However, population growth can account for sustainable growth in total output. Second, population growth explains why some countries fall into the category of rich countries and some other countries are categorized as poor (Herlambang et al. 2001). Therefore, the Solow model predicts that a country with high population growth will have lower GDP per person. According to the Solow model, a country with high population growth rates will have a steady state of low stock capital per worker. Third, population growth rate affects on the criteria in determining the golden rule level of capital accumulation.

Test results show that population growth shows a significant positive relationship with economic growth. This means that with increasing population will increase the economic growth. This is consistent with Solow theory of growth theory that potential source of economic growth, even with diminishing return to capital, is population growth (and technological advancement). This finding is also consistent with Johnson (1987) and Ismail et.al (2006) findings that faster population growth is not associated with slowing economic growth. 


\section{The effect of money supply (M) on economic growth}

The question of whether "money" affects or does not affect on "real" aspect of economy (in this case, output growth) is often referred as issue of net worth of money. Money is "neutral" if it does not affect the "real" sector and neutral if it is influential. This all ultimately depends on the proposed model. However, many economists now think that money is not neutral.

The answer to this question is crucial, because if money can indeed change the characteristics of equilibrium path, then this means that monetary policy (which is nothing but the policy to manage money in economy) can be used to influence the rate the growth of economy balance. And furthermore it can also be asked about what "optimal" monetary policy for economic growth (Boediono, 1981). Keynes ignores the classic view of acceleration of constant money because Keynes argue that prices are rigid which means changes in money supply will affect a little real activity. The money supply increases will increase output in short run, but when the money goes down it will reduce the output level in short run.

Another Solow model of economic growth also sees money stock as an important factor measured by purchasing power $(M / P)$. It will directly determine the output produced in economy, which will affect economic growth and income. The money circulation entry into the production function obviously will affect the long-term equilibrium position of economy. The above test results indicate that money supply circulation in community (M2) significantly avoids the output growth (GDP) in both the short and long term. While money circulation in narrow sense (M1) has only a short-term effect on output growth (GDP). This is theoretically relates to the issue of money neutrality. This is a problem to determine whether "money" affects or does not affect on "real" aspect of economy (in this case, output growth). Test results conclude that money is "not neutral" because it affects the real sector.

\section{CONCLUSION}

Based on observations and data analysis results on economic growth in Indonesia, then in this paper can be drawn some conclusions as follows:

1. Economic growth is a process to increase production of goods and services in economic activities of community. It can be said that development is single-dimensional and measured by higher production and income.

2. The economic growth model in this study is a simple Neoclassical theory model, which only wants to test the money neutrality entered as one inputs in production of goods and services.

3. The empirical test results indicate that economic growth is only affected by capital growth, population growth and money supply. It can be argued that classical opinion that money supply does not affect the real sector but only cause inflation is not true. In other word, money is not neutral.

Based on observations, data analysis results, and conclusion on economic growth in Indonesia, it can be drawn some suggestion as follows:

1. Economic growth is a priority in development. It cannot be seen only from activities to produce goods, but also needs to be seen in change in usage (allocation) of production resources among the sectors of economy, the changes in wealth and income sharing pattern among various groups of actors economic, and the changes of institutional framework in society life as a whole.

2. Economic growth cannot only be viewed on issues related to the physical inputs of production usage, but it should also look at role of money in production process 
activities. This is because money is a reflection of supply of goods and services produced. Higher money circulation in community makes company will produce more goods and services.

3. Process activities to produce goods and services in an economy should be focused on distribution issue. This is necessary due to the fact that population growth in developing country societies is faster. In relation to that rate of economic growth must be quite high in sense of surpassing the rate of population growth. If the rate of growth is only equal to the rate of population growth, then in such circumstances there is congestion or economic stagnation.

\section{REFERENCES}

Arintoko. 2011. Pengujian Netralitas Uang Dan Inflasi Jangka Panjang Diindonesia. Buletin Ekonomi Moneter dan Perbankan.

Boediono, 1981., Teori Pertumbuhan Ekonomi, Seri Sinopsis, Edisi Pertama. BPFE - UGM, Yogyakarta.

Gujarati, Damodar, 1995., Basic Econometrics, Third Edition, Mc Graw-Hill International Editions, Mc Graw-Hill, Inc, Singapore.

Hume, D. 1752. Of Money, Of Interest, and Of the Balance of Trade. In Essays, Moral, Political, and Literary, Reprinted in Hume, 1955, Writings on Economics, Eugene Rotwein ed. Accessed http://www.econlib.org/library/LFBooks/Hume/hmMPL.html.

Insukindro, 1990., Komponen Koefisien Regresi Jangka Panjang Model Ekonomi: Sebuah Studi Kasus Impor Barang di Indonesia. Jurnal Ekonomi dan Bisnis Indonesia, No.2, Vol.5.

Insukindro, 1993., Ekonomi Uang dan Bank; Teori dan Pengalaman di Indonesia, Edisi Pertama. Penerbit BPFE-UGM, Yogyakarta.

Ismail, Munawar. et.al, 2006. Bank dan Pertumbuhan Ekonomi; Temuan Baru dengan Menggunakan Data Regional. Jurusan Ekonomi Pembangunan, FE-UB. Malang.

Johnson, D. Gale, 1987. Is Population Growth The Dominant Force in Development?, Cato Journal, Vol. 7, No. 1.

King, Robert G dan Ross Levine, 1994. Capital Fundamentalism, Economic Development and Economic Growth, Carnegie-Rochester Conference Series on Public Policy, Vol. 40, June, Hal. 259-292.

King, Robert and Mark W. Waston. 1992. Testing Long Run Neutrality. National Bureu Of Economic Research.

Lucas, R.E. 1995. Monetary Neutrality. Prize Lecture, December 7, 1995. Accessed from http://nobelprize.org/economics/laureates/1995/lucas-lecture.pdf.

Mankiw, Gregory. N., 2002., Macroeconomics $5^{\text {th }}$ Edition. New York and Basingstoke, by Worth Publishers. Terjemahan, Penerbit Erlangga.

Puah, Chin-Hong; Habibullah, Muzafar Shah; Lau, Evan and Abu Mansor, Shazali. 2006. Testing long-run monetary neutrality in Malaysia: Revisiting divisia money. Paper Munich Personal RePEc Archive.

Sriyana, Jaka. 2003., Evolusi Ekonometrik Dinamik dalam Analisis Data Time Series., Jurnal Ekonomi \& Studi Pembangunan, Vol. 4. No. 2. FE Universitas Muhammadiyah, Yogyakarta.

Sulku, Seher Nur. 2011. Testing the Long Run Neutrality of Money in a Developing Country: Evidence from Turkey. Journal of Applied Economics and Business Research JAEBR, 1(2): 65-74 (2011).

Widarjono, Agus. 2005., Ekonometrika: Teori dan Aplikasi untuk Ekonomi dan Bisnis, Edisi Pertama. Penerbit Ekonisia Fakultas Ekonomi UII, Yogyakarta 
Management and Economics Journal (MEC-J)

22 Vol 1 (1) December 2017 